\title{
An Example to a Rare, Multisystemic and Challenging Metabolic Disorder: Peroxisomal Disease
}

\author{
Nadir, Multisistemik ve Zor Tanı Alan Doğumsal Metabolik \\ Hastalıklara Örnek Olarak Peroksizomal Hastalıklar
}

\author{
Asburce OLGAC ${ }^{1}$, Cigdem Seher KASAPKARA², Mustafa KILIC ${ }^{1}$
}

'University of Health Sciences, Dr. Sami Ulus Maternity and Child Health Training and Research Hospital, Ankara, Turkey

${ }^{2}$ Ankara Yılııım Beyazıt University, Ankara City Hospital, Department of Pediatric Metabolism, Ankara, Turkey

\begin{abstract}
Objective: Peroxisomal diseases (PDs) are autosomal recessively inherited inborn errors of metabolism (IEMs) that have a wide range of clinical presentations, with variable severity. The aim of this study was to describe cases with various subtypes of PDs with different clinical presentations and to increase the awareness of pediatricians to this metabolic disorder.

Material and Methods: The study was conducted in Dr. Sami Ulus Maternity and Child Health Treatment and Research Hospital, division of pediatric metabolism, between December 2020 and January 2021. Patients of whom very long chain fatty acids (VLCFAs) were analysed due to various conditions between January 2020 and December 2020 were retrospectively evaluated. Among patients that VLCFA analyses were performed, 71 tests were found to have abnormal results and 20 of these patients had undergone molecular genetic analysis with the suspicion of PDs. An underlying genetic pathology was detected in 6 patients. Data of patients were obtained from patients files.

Results: Six patients were evaluated. Diagnoses of patients were as following: Zellweger spectrum disorders $(n=4)$, rhisomelic chondrodysplasia punctata type $1(n=1)$, and AMACR deficiency $(n=1)$. Age of onset of clinical symptoms ranged from the neonatal period to 6 years. Main clinical symptoms were hypotonia, developmental delay and dysmorphic findings. Three patients had cataracts and 5 had sensorineural deafness. Elevated transaminases were detected in 5/6 patients, of whom 4 had abnormal liver function tests. VLCFAs were found to be elevated in all patients. Variants in PEX1, PEX5, PEX6, PEX7, PEX12, PEX 26 and AMACR genes were detected. Patients with liver insufficiency received cholic acid treatment.

Conclusion: PDs are very rare IEMs that comprise various subtypes with range of clinical phenotypes with different clinical presentations. Although genetic panel analyses is required for the diagnosis of, VLCFA analysis is a very simple and quick tool for the detection of PDs, and should be included in the screening of patients with visual and hearing impairments, liver disease and dysmorphic findings.
\end{abstract}

Key Words: Peroxisomal biogenesis disorders, PEX gene, Single peroxisomal enzyme deficiencies, Very long chain fatty acids, Zellweger spectrum disorders

(1)

OLGAC A

KASAPKARA CS

KILIC M
Conflict of Interest / Çıkar Çatışması: On behalf of all authors, the corresponding author states that there is no conflict of interest.

0000-0002-4989-221X :0000-0003-4642-5285 0000-0002-3569-276X

Contribution of the Authors / Yazarların katkısI: OLGAC A: Constructing the hypothesis or idea of research and/or article, Planning methodology to reach the Conclusions, Taking responsibility in patient follow-up, collection of relevant biological materials, data management and reporting, execution of the experiments, Taking responsibility in necessary literature review for the study, Taking responsibility in the writing of the whole or important parts of the study. KASAPKARA CS: Constructing the hypothesis or idea of research and/or article, Planning methodology to reach the Conclusions, Organizing, supervising the course of progress and taking the responsibility of the research/study, Taking responsibility in logical interpretation and conclusion of the results, Taking responsibility in the writing of the whole or important parts of the study, Reviewing the article before submission scientifically besides spelling and grammar. KILIC M: Constructing the hypothesis or idea of research and/or article, Organizing, supervising the course of progress and taking the responsibility of the research/study, Taking responsibility in logical interpretation and conclusion of the results, Taking responsibility in the writing of the whole or important parts of the study, Reviewing the article before submission scientifically besides spelling and grammar.

How to cite / Atıf yazım şekli : Olgac A, Kasapkara CS and Kilic M. An Example to Rare, Multisystemic and Challenging Metabolic Disorder: Peroxisomal Disease. Turkish J Pediatr Dis 2021;15:312-318.

Additional information / Ek bilgi: We thank Dr. Serdar Ceylaner for performing the molecular genetic analyses of the presented patients. 


\section{öz}

Amaç: Peroksizomal hastalıklar (PH'lar), otozomal resesif geçiș gösteren ve birçok farklı klinik șekilde ortaya çוkabilen doğumsal hastalıklardır. Bu çalışmada, kliniğimizde tanı alan ve izlenen PH tanısı almış olan olguların klinik ve laboratuvar bulgularının ve moleküler genetik özelliklerinin geriye dönük olarak incelenmesi planlanmıştır.

Gereç ve Yöntemler: Bu çalısma Dr. Sami Ulus Kadın Doğum, Çocuk Sağıı̆ı ve Hastalıkları Eğitim ve Araştırma Hastanesi, çocuk metabolizma bölümünde gerçekleştirildi. Ocak 2020 ile Aralık 2020 tarihlerinde, PH şüphesiyle çok uzun zincirli yağ asitleri (ÇUZYA) analizi yapılmış olan hastaların verileri derlendi. 1 yl içerisinde çeşitli gerekçelerle ÇUZYA analiz edilmiş olan hastalardan, 71 tanesinde anormal değerler tesbit edilmişti. Bu hastaların 20 tanesinde moleküler genetik analiz yöntemleri ile PH'lar araştııılıış ve 6 hastada tesbit edilmişti. Pozitif sonuç elde edilen hastaların verileri hasta dosyalarından derlendi.

Bulgular: Altı hastanın verileri geriye yönelik olarak incelendi. Hastaların tanıları şu şekildeydi: Zellweger sendromu (3 hasta), Rizomelik kondrodisplazi punktata tip 1 (2 hasta), AMACR eksikliği (1 hasta). Hastaların başvuru yaşları yenidoğan dönemi ve 6 yaş arasında değişmekteydi. Başlıca başvuru semptomları hipotoni, gelişme geriliği beslenme güçlüğü ve dismorfik yüz bulgularıydı. Tüm hastalarda multisistemik tutulum tesbit edildi. Hastaların laboratuvar incelemelerinde transaminaz yüksekliği en sık saptanan patolojik bulguydu. Bütün hastaların ÇUZYA analizinde yüksek değerler tesbit edildi. Hastaların hepsinde altta yatan genetik patoloji moleküler genetik analiz yöntemleri ile gösterildi (PEX1, PEX5, PEX6, PEX7, PEX12, PEX 26 ve AMACR genleri). Zellweger sendromu tanılı iki hastaya kolik asit tedavisi uyguland.

Sonuç: PH'lar nadir görülen ve farklı klinik bulgularla seyredebilen doğumsal metabolik hastalıklardır. Her ne kadar PH'ın kesin tanısında genetik panel analizleri kullanııs da, ÇUZYA analizi tanı için yönlendirici olan kolay ve hızlı bir tanısal testtir. Bu nedenle, özellikle görme ve işitme bozukluğu, karaciğer patolojisi ve dismorfik bulguları olan hastalarda tarama programlarına eklenmelidir.

Anahtar Sözcükler: Peroksizomal biyogenez bozuklukları, PEX geni, Peroksizomal enzim eksiklikleri, Çok uzun zincirli yağ asitleri analizi, Zellweger spectrum bozuklukları

\section{INTRODUCTION}

Peroxisomes are membrane-bound organelles responsible for important metabolic functions including $a$ and $\beta$ oxidation, glyoxylate detoxification, and ether phospholipid synthesis in many tissues. Defects in peroxisome formation and function impairs multiple metabolic pathways and result in multi systemic abnormalities (1).

Peroxisomal diseases (PDs) are autosomal recessively inherited inborn errors of metabolism (IEMs) that have a wide spectrum of clinical presentations, with variable severity. PDs are categorized into two main groups: Peroxisome biogenesis disorders (PBDs) and single peroxisomal enzyme deficiencies (SPEDs) (2).

PBDs are caused by defective peroxisome biosynthesis, assembly, and biochemical functions caused by variants in one of the w14 PEX genes that encode proteins related with peroxisome assembly called peroxins. They are characterized by multisystemic abnormalities ranging from a severe, neonatal onset disease to a mild form presenting in adulthood with nonspecific neurological findings. PBDs are mainly divided into 3 groups: Zellweger spectrum disorder (PBD-ZSD), rhizomelic chondrodysplasia punctata (RCDP) type 1 and type 5, and peroxisomal fission defects. Clinical symptoms are variable and are usually not specific to a subtype of disease (2). SPEDs occur due to defects of peroxisomal matrix enzymes and membrane proteins. Several subtypes have been defined (3).

Although genetic panels are required in the definitive diagnosis of PDs, analysis of very long chain fatty acids (VLCFAs) is known to be an easy laboratory test that can be very useful in the detection of these disorders (3).
Herein, we report 6 cases with PDs with different clinical presentations, that were all diagnosed after the detection of elevated VLCFAs.

\section{MATERIALS and METHODS}

The study was carried out between December 2020 and January 2021. Patients of whom very long chain fatty acids (VLCFAs) were analysed due to various conditions between January 2020 and December 2020 were retrospectively evaluated. Among patients that VLCFA analyses were performed, 71 tests were found to have abnormal results and 20 of these patients had undergone molecular genetic analysis with the suspicion of PDs. An underlying genetic pathology was detected in 6 patients. Patients that were diagnosed as various sub-types of PDs were retrospectively evaluated. Demographic data including age, sex, consanguinity of parents, age of admission and diagnosis, clinical findings and the results of molecular genetic analyses were collected from patient files. The study was approved by the ethics committee of Ankara City Hospital (number:1078).

\section{Patient-1:}

9 months old male patient was referred to our center due to dysmorphic findings, hypotonicity and difficulty in feeding. He was the first child of consanguineous parents (First degree cousins) of Turkish origin. He was born by cesarean section on the $36^{\text {th }}$ week, due to intrauterine growth retardation (IUGR). He was administered to the neonatal intensive care unit (NICU), after an uncomplicated delivery, and mechanical ventilation was applied due to transient tachypnea of the newborn. He was referred to our center for further evaluation. Physical examination 
upon admission showed weight of $3500 \mathrm{~g}$ (Below -2 standard deviation score [SDS]), height of $51 \mathrm{~cm}(<-2$ SDS) and head circumference of $35 \mathrm{~cm}(<-2 \mathrm{SDS})$, a dysmorphic facial appearance including dolichocephaly, a flat occiput, maxillary hypoplasia, a long flat philtrum, a wide nasal base and hypoplasia of the anterior nasal spine, bilateral cataracts, shortness of the proximal segments of the long bones, and contractures of arms and legs, and axial hypotonicity (Figure 1). Laboratory analyses showed normal complete blood count (CBC), biochemistry, ammonia, vitamin B12, folic acid, homocysteine, thyroid function tests, and lactate levels. Metabolic tests including acylcarnitine analysis by dried blood spot, and urine amino acid analyses, and transferrin isoelectric focusing of serum were inconclusive. Very long chain fatty acid (VLCFA) analysis that was performed with the suspicion of RCDP type 1, showed elevated phytanic acid levels. The molecular genetic analysis of the PEX7 gene showed homozygous c.842delC (p.T281Kfs*12) mutation that was previously reported to cause RCDP type 1 .

\section{Patient-2:}

A fourteen-month-old girl was referred to our center with the suspicion of a neurometabolic disorder due to delay in developmental milestones and seizures. She was born at gestational age 37 weeks and weighed $2700 \mathrm{gr}$ at birth $\left(50^{\text {th }}\right.$. $75^{\text {th }}$ percentile). She required oxygen and was hospitalized in NICU due to hypotonia. At age 6 months she had startleinduced seizures, and electroencephalogram (EEG) showed, paroxysmal generalized spike-slow wave activity. Levatiracetam treatment was initiated. Ophtalmological examination revealed optic disc atrophy and papiledema. Cochlear implant operation was planned due to sensorineural deafness. Initial physical examination revealed growth retardation (weight: $6500 \mathrm{gr}$ (<-2 SDS), height: $68 \mathrm{~cm}(<-2$ SDS), head circumference: $43 \mathrm{~cm}(<-2$ SDS). Transaminases were found to be elevated (Aspartate aminotransferase (AST): 282 U/L, NR: 0-40, alanine aminotransferase (ALT): 78, NR:0-40). Coagulation parametres were also elevated to be elevated (International normalized ratio [INR]: 1.8, NR:0.8-1.2). Although most of the metabolic tests were inconclusive, VLCFA analysis showed elevated phytanic and C26:0 acids. Ursodeoxycolic acid (UDCA), and fat soluble vitamins (vitamin A, D, E and $K$ ) treatments were initiated, along with low phytanic acid diet. The initial diagnosis was ZSDs, and a genetic panel of peroxisomal genes revealed a compound heterozygous mutation in the PEX6 gene that was previously reported to cause ZSD. Cholic acid (CA) treatment $15 \mathrm{mg} /$ $\mathrm{kg} /$ day was initiated after diagnosis. A slight improvement in transaminases and INR was observed soon after. She is now 3 years 6 months old with ongoing supportive therapy and CA.

\section{Patient-3:}

One-month old male infant was referred to our center due to hypoactivity. He was the first child of consanguineous parents of Turkish origin. IUGR and intracranial unilateral ventriculmegaly were detected at the $35^{\text {th }}$ gestational week. He was followed-

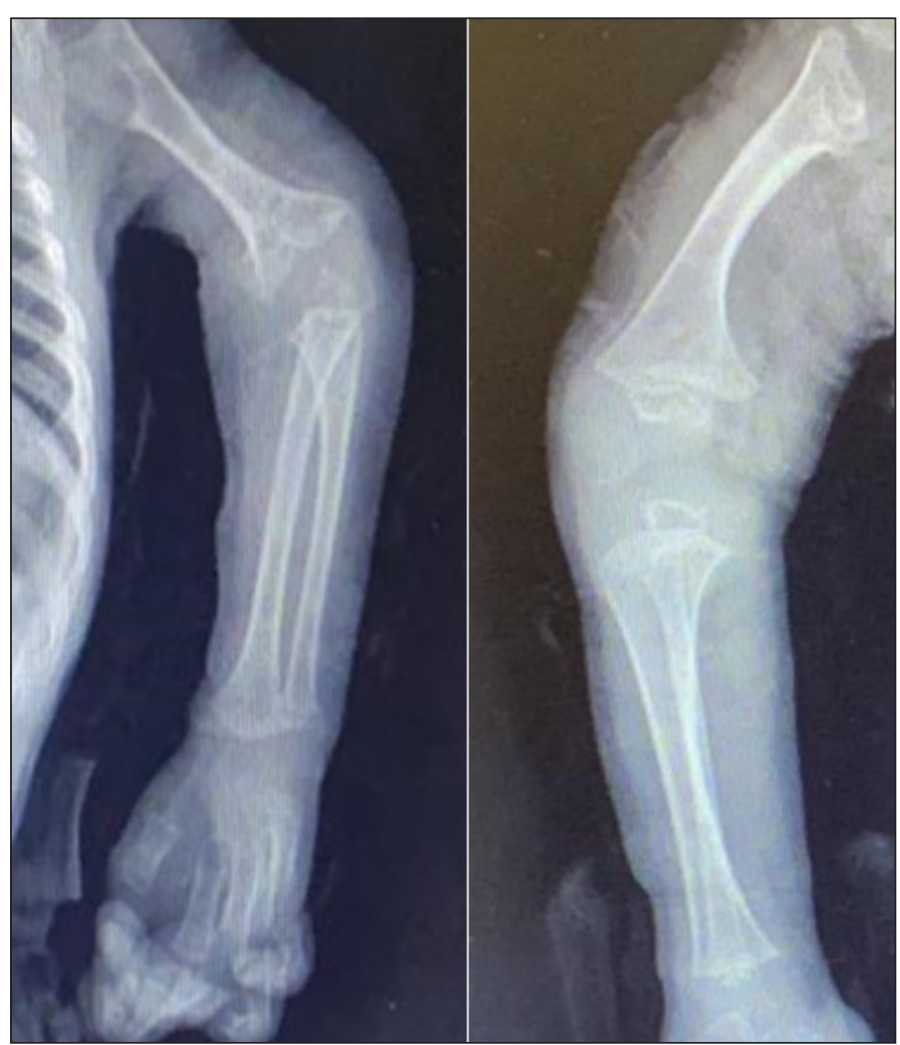

Figure 1: X-rays of Patient-1 demonstrating rhisomelic chondrodysplasia punctata

up in the NICU for a month, and was referrd to our center, afterwards. Upon admission, physical examination showed axial hypotonia, dysmporphic facial findings including hypertelorism, low-set ears, depressed nasal bridge, micrognathia, higharched palate and short digits. He was being fed by an orogastric feeding tube. Abdominal ultrasound showed multiple cyctic appearance of both kidneys. Transaminases were found to be markedly elevated (AST: 1412 U/L, ALT: 316 U/L). Viral markers including hepatitis $\mathrm{A}, \mathrm{B}$ and $\mathrm{C}$, and $\mathrm{TORCH}$ panel were negative. Alpha-1 antithyripsine was within normal limits. Coagulation parameters were found to be elevated (Activated partial thromboplastin time [aPTT]: 36.4, INR: 1.28). VLCFA analysis showed elevated C26:0, C26:0/C22:0, and C24:0/ C22:0. Echocardiogram revealed perimembranous septal anevrism and ASD. EEG was performed due to generalized seizures, that showed epileptic activity originating from both frontotemporal areas. Cranial magnetic resonance imaging (MRI) revealed dysmorphic appearance of corpus callosum and polymicrogyria at both frontotemporal hemispheres. A previously reported c.888_889delCT (p.L279Tfs*12) homozygous variant was detected in the PEX12 gene, that was reported to cause ZSD, by the panel analysis of PEX genes. Unfortunately, the patient died when he was 3 months old, due to liver failure.

\section{Patient-4:}

Three-year-old male patient was referred to our clinic due to hypotonia. He was the second child of consanguineous parents of Turkish origin. He was diagnosed with Hirschprung's 
Disease, at the second postnatal day, and was under routine follow-up. Sensorineural deafness was detected when he was 6 months old. Initial physical examination revealed normal findings except clinodactily. Ophtalmological examination was normal. Cranial MRI and EEG revealed normal findings. CBC, coagulation parameters, and biochemistry were normal, apart from slightly elevated AST levels (59 U/L). Elevated phytanic acid, C26:0, C26:0/C22:0, and C24:0/C22:0 levels were found in VLCFA analysis. Two distinct homozygous mutations were detected in PEX gene analysis (PEX5 c.753+6A>G - a novel mutation, and PEX26 c.353C>G -a previously reported variant that was defined to have unknown significance). Fat soluble vitamins were supplemented. CA treatment $15 \mathrm{mg} / \mathrm{kg} / \mathrm{d}$ was initiated. The patient is under CA therapy for 1.5 years for now and is clinically stable.

\section{Patient-5:}

Ten-year-old boy was admitted to our clinic due to elevated tranaminases, initially noticed when he was a year old in an external center, but he was lost to follow-up after age 5 . Upon admission, physical examination was normal, including the neurological system, and his growth centiles were within normal limits. Laboratory analyses revealed elevated transaminases (AST: $118 \mathrm{U} / \mathrm{L}$, ALT: $135 \mathrm{U} / \mathrm{L}$ ). Viral markers, alpha-1 antithriypsine, ferritine, celiac markers and 24 hours copper excretion in urine were within normal limits. Metabolic tests were performed to unravel the ethiology of transaminase elevation. VLCFA analysis showed elevated pristanic acid, C26:0, and C 26:0/C22:0. PEX gene panel analysis showed a novel c.194T>G homozygous variant in the AMACR gene. Lowphytanic acid diet along with UDCA and fat-slouble vitamins was initiated. He is under closed follow-up for any neurological finding that may occur in time.

\section{Patient-6:}

Three-year-old girl was referred due to liver failure. She was the second child of consanginous Turkish parents. She was born at term after an uncomplicated pregnancy, and was admitted to the NICU soon after birth due to hypotonia and difficulty in feeding, where she was followed-up for 3 months. Her developmental milestones were delayed, and was operated for congenital cataracts when she was 6 months old. She had a hearing implant due to sensorineural deafness. She was referred to our center when hepatomegaly and liver failure was noticed. Upon admission, she was pale and lethargic. Her growth centiles were as following: Weight $12 \mathrm{~kg}$ (10 p), height $83 \mathrm{~cm}(<3 \mathrm{p})$. Liver was palpated $6 \mathrm{~cm}$ under the left mid clavicular line. She was anemic, and AST level was found to be elevated. INR was elongated (1.4). VLCFA analysis showed elevated phytanic, pristanic and C26:0 levels. Dietary treatment and CA was started with the diagnosis of ZSD. The molecular genetic analysis of the PEX1 gene showed a homozygous c. $2528 \mathrm{G}>\mathrm{A}$ variant that is previously known to cause ZSD. INR levels lowered after CA treatmant. She is now 8 years old, still being followed-up in our center with a stable clinical condition.

\section{RESULTS}

The main reasons for VLCFA analyses in our patient group were dysmorphic findings liver disease, deafness and cataracts. Among 71 patients whose VLCFA analyses were found to be abnormal, 20 patients had undergone molecular genetic analysis due to suspicion of PDs. Among these patients, 6 turned out to have various subtypes of PDs. Data of the mentioned patients with various subtypes of PDs were evaluated retrospectively from patient files. The demographic and clinical data of patients are shown in Table I. Subtypes of PDs of the patients were as following: ZSDs $(n=4), R C D P$ type $1(n=1)$, and AMACR deficiency $(n=1)$ were defined. Male to female ratio was $4 / 2$. Parental consanguinity was present in 5 out of 6 patients.

Age of onset of clinical symptoms ranged from the neonatal period to 6 years. Age of diagnosis ranged from 2 months to 11 years. Dysmorphic findings were present in 5 out of 6 patients. Microcephaly was present in 4 out of 6 patients. Feeding problems were seen in $4 / 6$ patients. Four patients were hypotonic, and 5 had developmental delay. Three patients had cataracts and 5 had sensorineural deafness. One patient had skeletal findings. Cardiac findings including focal septal hypertrophy, ventricular septal defect, mitral stenosis and patent foramen ovale were detected. Elevated transaminases were detected in $5 / 6$ patients, of whom 4 had abnormal liver function tests. Three patients had renal findings including polycystic kidneys and proteinuria.

VLCFAs were found to be elevated in all patients, including phytanic acid (4 patients), pristanic acid (4 patients), C26:0 (5 patients), C26:0/C22:0 (4 patients), C24:0/C22:0 (3 patients), C 22:0 (1 patient) and C24:0 (1 patient).

The following genetic variants were detected by molecular genetic analysis. PEX1, PEX5, PEX6, PEX7, PEX12, PEX 26 and AMACR gene. Four out of 6 patients were given low phytanic acid diet, and patients with liver insufficiency received cholic acid treatment (15 mg/kg/d).

\section{DISCUSSION}

Peroxisomes play an important role in a variety of cellular metabolic pathways. Peroxisomal disorders may deteriorate specific pathways (SEPDs), or lead to a generalized defect in function, assembly and maintenance of peroxisomes (PBDs). Although being rare individually, the estimated all PDs in total is 1 in 5000 . The most commonly encountered disease of PBD is X-linked adrenoleukodystrophy (X-ALD), caused by mutations of $A B C D 1$ gene. PBDs include defects of peroxisomal matrix 


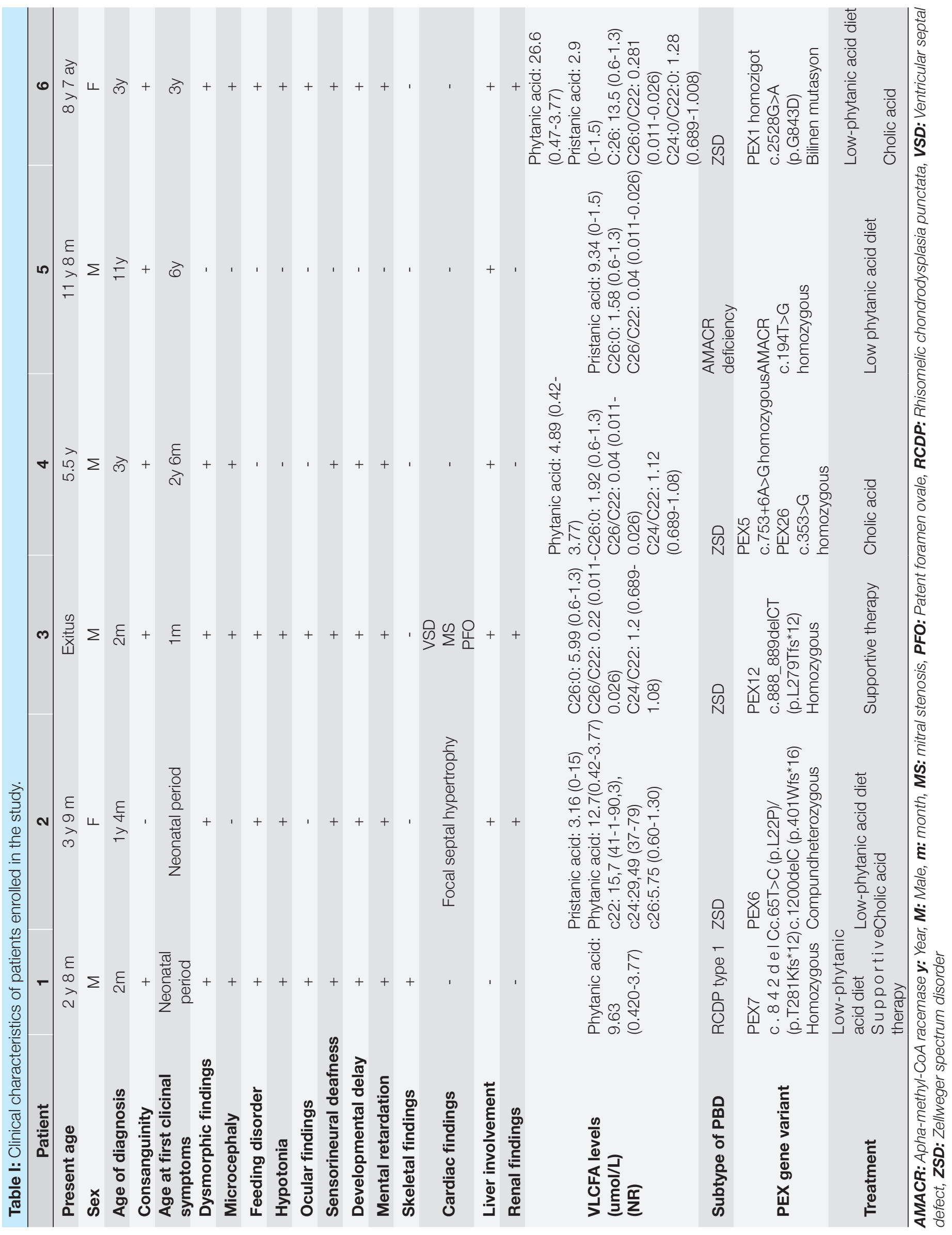


enzymes and membrane proteins involved in metabolite transport (2).

PBD-ZSD's include three clinical types ranging from severe (Zellweger syndrome-ZS), intermediate (neonatal adrenoleukodystrophy), and mild (infantile Refsum disease) subtypes respectively (4). Main clinical feature of ZSDs are liver dysfunction, cholestasis, hepatosplenomegaly, renal cycts, developmental delay, neurological abnormalities including severe hypotonia, seizures, neuropathy, ataxia, deafness, and vision impairment and vision impairment, coagulopathy, and dysmorphic features including a large anterior fontanelle, prominent forehead, shallow orbital ridges, high arched palate, broad nasal bridge, small nose, antevert nares $(1,2,5)$. In patients with a more severe phenotype presenting in the neonatal period (as in ZS), liver fibrosis, biliary cirrhosis and feeding disorders are present. Patients with a severe phenotype usually die in the first year of life (6). Cranial MRI may demonstrate cortical dysplasia (polymicrogyria), generalized decrease in white matter volume, delayed myelination, bilaterial ventricular dilatation and germinolytic cysts (3).

Among the 6 patients we have presented, 4 were diagnosed as ZSDs. In accordance with the literature, all of them had neurological findings (mainly hypotonia, feeding problems and developmental delay), along with ocular findings (cataracts), sensorineural deafness and liver disease. Microcephaly and dysmorphic findings were present in the majority of patients with ZSDs. Cardiac and renal findings were also present.

In ZSDs, bile acid synthesis is upregulated by decreased levels of C24-bile acids, that causes increased accumulation of C27- bile acid intermediates. VLCFAs, phytanic, pristanic and pipecolic acid in plasma are elevated (6). In accordance with the literature, all of the presented patients with ZSDs, had elevated VLCFA levels, mainly phytanic acid, that could easily be detected in VLCFA analysis. Our study also underlines the importance of VLCFA analysis, in the diagnosis of PDs.

The PEX1 and PEX6 genes are commonly affected in ZSDs (2). In our study, variants in 5 different PEX studies were identified including PEX1, PEX5, PEX6, PEX7 and PEX26 genes. Among them, three were previously reported to be related with PBDs. One patient was found to carry two different homozygous mutations in PEX5 (novel mutation) and PEX26 (previously defined as variance of uncertain significance ) genes. While 4 of these variants were related with ZSDs, the variant in PEX7 gene were found to be related with RCDP type 1 .

RCDP is an autosomal recessively inherited PD, with estimated prevalence to be $1 / 100.000$. The main features of this disorder are skeletal abnormalities, mental retardation, contractures, cataract, recurrent respiratory infections and breathing problems. Seizures and dysmorphic findings are is also associated with this pathology (7). The stippled calcification of cartilage tissue can easily be observed in $\mathrm{x}$-rays that may be helpful in diagnosis. Five subtypes of RCDP have been defined up-to-date. Three of them (RCDP type 2, RCDP type 3 and RCDP type 4) are SPEDs, while RCDP type 1 and RCDP type 5 are PBDs. RCDP type 1 is caused by the homozygous or compound heterozygous mutations in the PEX7 gene, that encodes the PTS2-protein receptor. Pathogenic variants of this gene lead to defective plasmalogen synthesis and a-oxidation of phytanic acid in peroxisomes. Thus, VLCFA analysis may be helpful in diagnosis by demonstrating elevated phytanic acid levels. Genetic panel analysis may be required for the subtype of RCDP to be unraveled, since most subtypes are clinically indistinguishable. Although there is no curative treatment, dietary limitation of phytanic acid is recommended (1). Our presented case with RCDP type 1 was initially suspected to have a PD due to skeletal and dysmorphic findings, along with elevated levels of phytanic acid in VLCFA analysis. Although genetic analysis was essential to unravel underlying etiology, VLCFA analysis was a helpful diagnostic tool.

Alpha-methyl-Coa racemase (AMACR) deficiency, is categorized among SEPDs, and is usually adult-onset with variable presentations, including peripheral neuropathy, relapsing encephalopathy, epilepsy, tremor, cataract, and pigmentary retinopathy (8). It may rarely present in the neonatal period by cholestatic liver disease and vitamin $\mathrm{K}$ deficiency, along with neurological manifestations. (9). The disease is caused by the variations in the AMACR gene on chromosome 5p13.2$5 q 11.1$, that encodes the AMACR enzyme that is located in both peroxisomes and mitochondria, and is responsible for the elimination of methyl-branched fatty acids and synthesis of bile acids. Serum pristanic acid and C27 bile acid intermediates are found to be elevated (1). The presented case with AMACR deficiency is unique in the way that it presented with transaminase elevation without any neurological signs or elevated creatine levels or apparent liver disease. The variant detected in AMACR gene is a novel mutation that is predicted to be moderately pathogenic in various databases. Parental studies are being carried out.

As our presented case series have demonstrated, being rare diseases, the diagnosis of PDs is difficult based on exclusively clinical findings. Proper history and detailed physical examination is extremely important.

Unfortunately, no definite therapy for patients with PDs exists. Low phytanic acid diet is recommended in ZSDs with very high phytanic acid levels (3). CA is suggested to be a potential therapy in ZSDs by suppressing the first step in biosynthesis of bile acids, and causes reduced levels of bile acid intermediates. Also, CA restores the diminished CA levels, and improves bile flow and solubility of dietary fats and fat-soluble vitamins (10). In our patient series, among 4 patients with ZSDs, 3 patients were under CA therapy for 1 to 4 years, and although not being normalized, all of the patients were stabilized in terms of liver functions. One patient died due to liver failure, soon after diagnosis. 
PDs comprise various subtypes with range of clinical phenotypes with different clinical presentations. Although panel analysis of PEX genes is required for the diagnosis of, VLCFA analysis is a very simple and quick tool for the detection of peroxisomal disordes, and should be included in the screening of patients with visual and hearing impairments, and liver disease. Since a partial metabolic treatment is available, pediatricians must be aware of this rare but likely underdiagnosed disease spectrum.

\section{REFERENCES}

1. Braverman NE, D'Agostino MD, Maclean GE. Peroxisome biogenesis disorders: Biological, clinical and pathophysiological perspectives. Dev Disabil Res Rev 2013;17:187-96.

2. Waterham HR, Ferdinandusse S, Wanders RJ. Human disorders of peroxisome metabolism and biogenesis. Biochim Biophys Acta $2016 ; 1863: 922-33$.

3. Klouwer FC, Berendse K, Ferdinandusse S, Wanders RJ, Engelen M, Poll-The BT. Zellweger spectrum disorders: clinical overview and management approach. Orphanet J Rare Dis 2015;10:151.

4. Steinberg SJ, Raymond GV, Braverman NE, Moser AB. Peroxisome biogenesis disorders, Zellweger syndrome spectrum. In: Pagon RA, Adam, MP, Ardinger $\mathrm{HH}$, et al., editors. GeneReviews ${ }^{\circledR}$
[Internet]. University of Washington; Seattle, Seattle (WA): Dec 12. 2003 (1993- 2015. Available from: http://www.ncbi.nlm.nih.gov/ books/NBK1448/, Updated 2012 May 10)

5. Gould S, Raymond G, Valle D. The peroxisome biogenesis diosorders. In: The metabolic and molecular bases of inherited disease, 8th edn. McGraw-Hill 2001; 3181-218.

6. Keane MH, Overmars H, Wikander TM, Ferdinandusse S, Duran M, Wanders RJ, et al. Bile acid treatment alters hepatic disease and bile acid transport in peroxisome-deficient PEX2 Zellweger mice. Hepatology 2007;45:982-97.

7. Braverman N, Chen L, Lin P, Obie C, Steel G, Douglas P, et al. Mutation analysis of PEX7 in 60 probands with rhizomelic chondrodysplasia punctata and functional correlations of genotype with phenotype. Hum Mutat 2002;20:284-97.

8. Smith EH, Gavrilov DK, Oglesbee D, Freeman WD, Vavra MW, Matern D, et al. An adult onset case of alpha-methyl-acyl-CoA racemase deficiency. J Inherit Metab Dis 2010;33 Suppl 3:S34953.

9. Gündüz M, Ünal Ö, Küçükçongar-Yavaş A, Kasapkara Ç. Alpha methyl acyl CoA racemase deficiency: Diagnosis with isolated elevated liver enzymes. Turk J Pediatr 2019;61:289-91.

10. Berendse K, Klouwer FC, Koot BG, Kemper EM, Ferdinandusse $\mathrm{S}$, Koelfat KV, et al. Cholic acid therapy in Zellweger spectrum disorders. J Inherit Metab Dis 2016;39:859-68. 